\title{
Sinfonevada: Dataset of Floristic diversity in Sierra Nevada forests (SE Spain)
}

\author{
Antonio Jesús Pérez-Luque', Francisco Javier Bonet', Ramón Pérez-Pérez', \\ Rut Aspizua ${ }^{3}$, Juan Lorite, Regino Zamora ${ }^{1,2}$
}

I Laboratorio de Ecología (iEcolab), Instituto Interuniversitario de Investigación del Sistema Tierra en Andalucia (CEAMA), Universidad de Granada, Avenida del Mediterráneo s/n, 18006, Granada, Spain 2 Grupo de Ecología Terrestre, Departamento de Ecología, Universidad de Granada, Facultad de Ciencias, Campus de Fuentenueva s/n, 18071, Granada, Spain 3 Agencia de Medio Ambiente y Agua de Andalucía. Consejería de Medio Ambiente y Ordenación del Territorio. Junta de Andalucía, Cl Joaquina Egüaras, 10, 18003, Granada, Spain 4 Departamento de Botánica, Universidad de Granada, Facultad de Ciencias, Campus de Fuentenueva s/n, 18071, Granada, Spain

Corresponding author: Antonio Jesús Pérez-Luque (ajperez@ugr.es)

Academic editor: V. Chavan | Received 1 October 2013 | Accepted 5 February 2014 | Published 17 February 2014

Citation: Pérez-Luque AJ, Bonet FJ, Pérez-Pérez R, Aspizua R, Lorite J, Zamora R (2014) Sinfonevada: Dataset of Floristic diversity in Sierra Nevada forests (SE Spain). PhytoKeys 35: 1-15. doi: 10.3897/phytokeys.35.6363 Resource ID: GBIF Key: http://www.gbif.org/dataset/db6cd9d7-7be5-4cd0-8b3c-fb6dd7446472

Resource citation: University of Granada-Andalusian Environmental Center (2013) Sinfonevada: Dataset of floristic diversity in Sierra Nevada forests (SE Spain), Spain. 7920 data records. Contributed by TRAGSA, University of Granada, OBS- NEV, Pérez-Luque AJ, Pérez-Pérez R, Bonet FJ, Aspizua R, Lorite J, Zamora R. Online at http:// www.gbif.es:8080/ipt/resource.do?r=sinfonevada and http://obsnev.es/noticia.html?id=5307, version 1.0 (last updated on 2013-08-01). Resource ID: GBIF Key: http://www.gbif.org/dataset/db6cd9d7-7be5-4cd0-8b3c-fb6dd74446472, Data Paper ID: doi: 10.3897/phytokeys.35.6363

\begin{abstract}
The Sinfonevada database is a forest inventory that contains information on the forest ecosystem in the Sierra Nevada mountains (SE Spain). The Sinfonevada dataset contains more than 7,500 occurrence records belonging to 270 taxa ( 24 of these threatened) from floristic inventories of the Sinfonevada Forest inventory. Expert field workers collected the information. The whole dataset underwent a quality control by botanists with broad expertise in Sierra Nevada flora. This floristic inventory was created to gather useful information for the proper management of Pinus plantations in Sierra Nevada. This is the only dataset that shows a comprehensive view of the forest flora in Sierra Nevada. This is the reason why it is being used to assess the biodiversity
\end{abstract}

Copyright Antonio Jesús Pérez-Luque et al. This is an open access article distributed under the terms of the Creative Commons Attribution International License (CC BY 4.0), which permits unrestricted use, distribution, and reproduction in any medium, provided the original author and source are credited. 
in the very dense pine plantations on this massif. With this dataset, managers have improved their ability to decide where to apply forest treatments in order to avoid biodiversity loss. The dataset forms part of the Sierra Nevada Global Change Observatory (OBSNEV), a long-term research project designed to compile socio-ecological information on the major ecosystem types in order to identify the impacts of global change in this area.

\section{Keywords}

Sierra Nevada, Spain, floristic inventories, vascular plant, Liliopsida, Magnoliopsida, global-change monitoring, occurrence, observation

\section{Project details}

Project title

Sierra Nevada Global Change Observatory (OBSNEV)

\section{Personnel}

Regino Jesús Zamora Rodríguez (Principal Investigator)

\section{Funding}

All the information contained in Sinfonevada was gathered by TRAGSA (Transformación Agraria S.A.), a public company funded by the Spanish Ministry of the Environment. The Sierra Nevada Global Change Observatory is funded by the Andalusian Regional Government (via Environmental Protection Agency) and by the Spanish Government (via "Fundación Biodiversidad", which is a Public Foundation).

\section{Study area descriptions/descriptor}

Sierra Nevada (Andalusia, SE Spain), is a mountainous region with an altitudinal range between $860 \mathrm{~m}$ and $3482 \mathrm{~m}$ a.s.l. covering more than $2000 \mathrm{~km}^{2}$ (Figure 1). The climate is Mediterranean, characterized by cold winters and hot summers, with pronounced summer drought (July-August). The annual average temperature decreases in altitude from $12-16^{\circ} \mathrm{C}$ below $1500 \mathrm{~m}$ to $0^{\circ} \mathrm{C}$ above $3000 \mathrm{~m}$ a.s.l., and the annual average precipitation is about $600 \mathrm{~mm}$. Additionally, the complex orography of the mountains causes strong climatic contrasts between the sunny, dry south-facing slopes and the shaded, wetter north-facing slopes. Annual precipitation ranges from less than $250 \mathrm{~mm}$ in the lowest parts of the mountain range to more than $700 \mathrm{~mm}$ in the summit areas. Winter precipitation is mainly in the form of snow above $2000 \mathrm{~m}$ of altitude. The Sierra Nevada mountain range hosts a high number of endemic plant species 


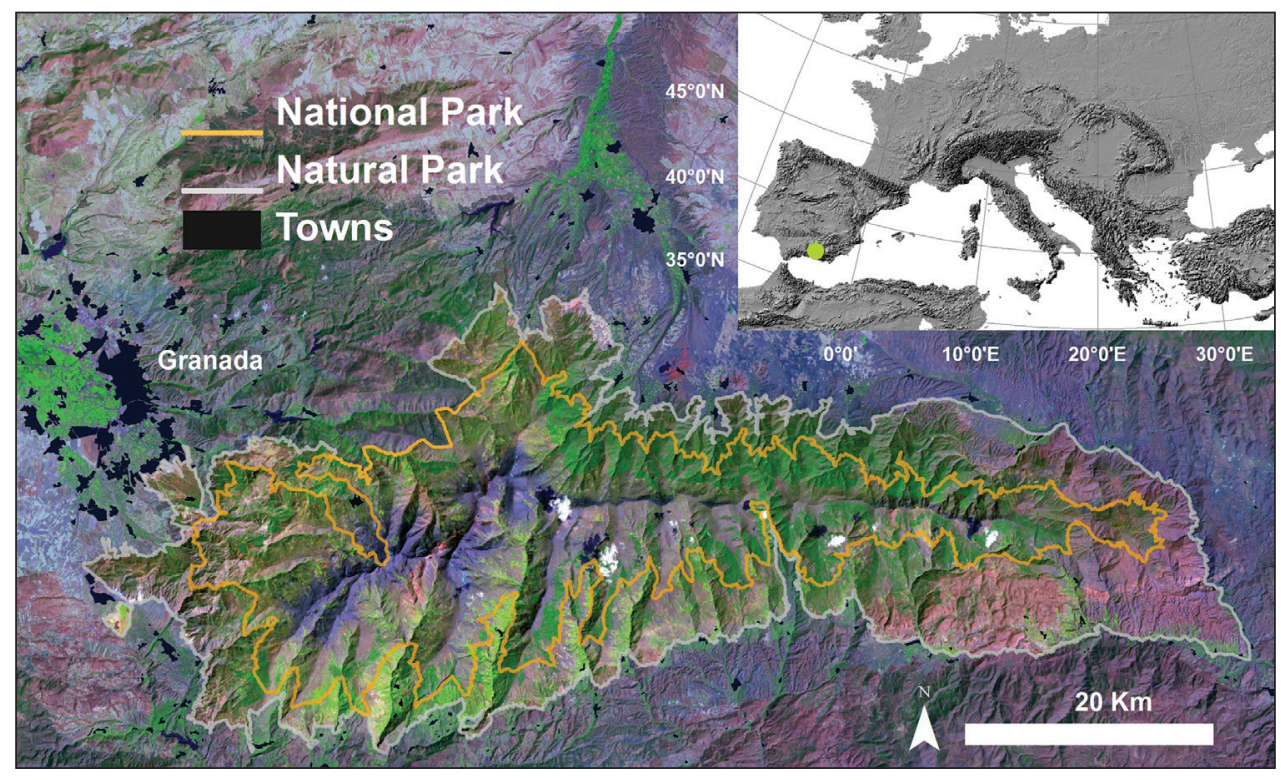

Figure I. Location of Sierra Nevada mountain (southern Spain). The boundaries of the National and Natural Parks are shown. We used a Landsat 5 image (2001) as background.

(c. 80; Lorite et al. 2007) for a total of 2,100 species of vascular plants (25\% and $20 \%$ of Spanish and European flora, respectively), being considered one of the most important biodiversity hotspots in the Mediterranean region (Blanca et al. 1998).

This mountain range has several legal protections: Biosphere Reserve MAB Committee UNESCO; Special Protection Area and Site of Community Importance (Natura 2000 network); and National Park. The area includes 61 municipalities with more than 90,000 inhabitants. The main economic activities are agriculture, tourism, cattle raising, beekeeping, mining, and skiing (Bonet el al. 2010).

\section{Design description}

Sierra Nevada Global Change Observatory (OBSNEV) (Bonet et al. 2011) is a longterm research project which is being undertaken at Sierra Nevada Biosphere Reserve (SE Spain). It is intended to compile the information necessary for identifying as early as possible the impacts of global change, in order to design management mechanisms to minimize these impacts and adapt the system to new scenarios (Aspizua et al. 2010, Bonet el al. 2010). The general objectives are to:

- Evaluate the functioning of ecosystems in the Sierra Nevada Nature Reserve, their natural processes and dynamics over a medium-term timescale.

- Identify population dynamics, phenological changes, and conservation issues regarding key species that could be considered indicators of ecological processes. 
- Identify the impact of global change on monitored species, ecosystems, and natural resources, providing an overview of trends of change that could help foster ecosystem resilience.

- Design mechanisms to assess the effectiveness and efficiency of management activities performed in the Sierra Nevada in order to implement an adaptive management framework.

- Help to disseminate information of general interest concerning the values and importance of Sierra Nevada.

The Sierra Nevada Global Change Observatory has four cornerstones (Figure 2): 1) a monitoring program with 40 methodologies that collect information on ecosystem functioning; 2) an information system to store and manage all the information gathered; 3) a plan to promote adaptive management of natural resources using the knowledge amassed through the monitoring programme; and 4) an outreach program to disseminate all the available information to potential users.

\section{Observatorio \\ Cambio Global \\ Sierra Nevada}

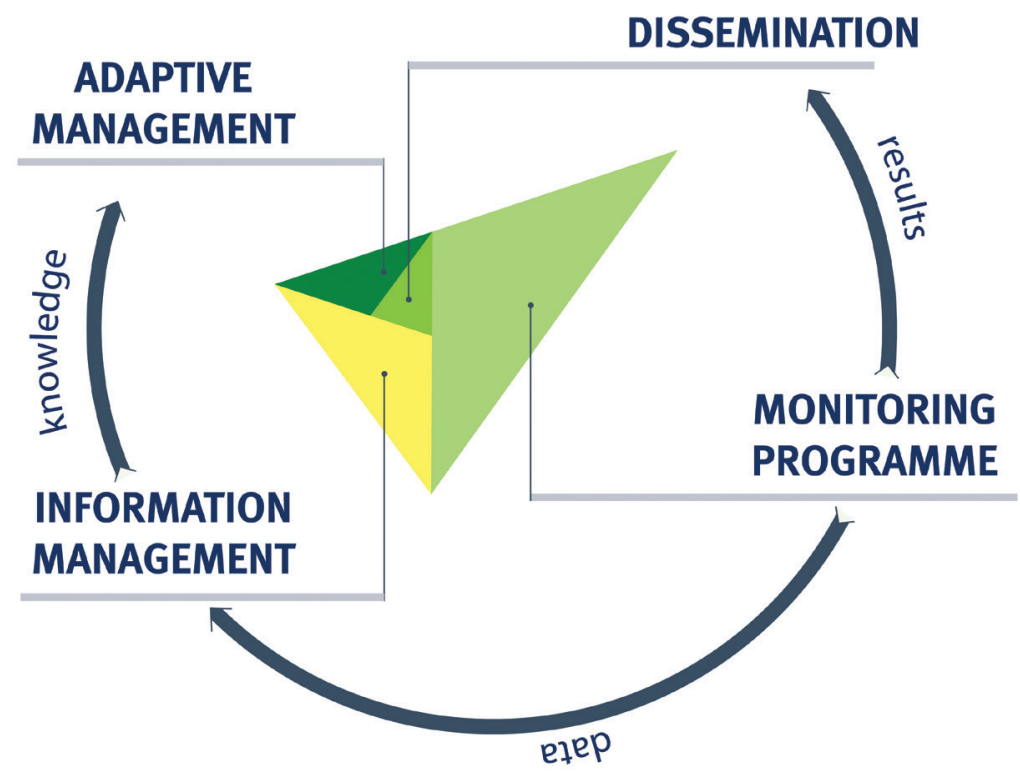

Figure 2. Structure of the Sierra Nevada Global Change Observatory. The four cornerstones of the research project are shown: monitoring program, adaptive management, information systems and dissemination. A monitoring program is needed to identify the impacts of global change over Sierra Nevada. The information compiled needs to be transformed into useful knowledge for the managers to carry out an active and adaptive management of natural resources. To achieve this, it is essential that all data be integrated and analysed in an information system. Finally, the general public should be informed of both the results obtained and methodologies used, through effective outreach activities. 
The Sierra Nevada Global Change Observatory is linked to other national (Zamora and Bonet 2011) and international monitoring networks: GLOCHAMORE (Global Change in Mountain Regions) (Björnsen 2005), GLOCHAMOST (Global Change in Mountain Sites) (Schaaf 2009), LTER-Spain (Long-Term Ecological Research).

Sierra Nevada Global Change Observatory is collecting socio-ecological information on the major ecosystem types found in Sierra Nevada. This information is being integrated in an Information System (http://obsnev.es/linaria.html - Pérez-Pérez et al. 2012. (Free access upon registration). The dataset described here is a good example of this idea. We have created a relational database to store the floristic inventories prepared in 2004-2005. Thanks to this work, all this valuable and unique information will be available to scientists and environmental managers worldwide.

\section{Data published through}

GBIF: http://www.gbif.es:8080/ipt/resource.do?r=sinfonevada

\section{Taxonomic coverage}

\section{General taxonomic coverage description}

Most of the species recorded in the inventories belong to class Magnoliopsida $(6,042$ records; $76.28 \%)$ and Liliopsida (1,171 records; $14.78 \%)$. The top 10 of the orders (Figure 3) include Poales (1153 records; $14.56 \%$ ) for the class Liliopsida, Lamiales (1062 records; $13.41 \%$ ) for Magnoliopsida and Pinales (569 records; $7.18 \%$ ). In these collection, 57 families are represented, with Poaceae, Fabaceae, and Lamiaceae being the families with major number of records (Table 1) (Figure 3). The collection includes 270 taxa belonging to 159 genera, Pinus and Thymus being the most represented ones in the database. There are 24 threatened taxa (Table 2).

\section{Taxonomic ranks}

Kingdom: Plantae

Phylum: Pteridophyta, Spermatophyta

Class: Gnetopsida, Liliopsida (Monocotyledones), Magnoliopsida (Dicotyledones), Pinopsida, Polypodiopsida

Order: Apiales, Asparagales, Asterales, Brassicales, Caryophyllales, Cucurbitales, $\mathrm{Cu}-$ pressales, Dipsacales, Ephedrales, Ericales, Fabales, Fagales, Gentianales, Geraniales, Lamiales, Liliales, Malpighiales, Malvales, Pinales, Poales, Polypodiales, Ranunculales, Rosales, Santalales, Sapindales, Saxifragales, Solanales, Umbellales 
Table I. The top 20 of the families represented in the collection.

\begin{tabular}{l|l|l}
\hline Family & records & $\%$ \\
\hline Poaceae & 1139 & 14.38 \\
\hline Fabaceae & 1055 & 13.32 \\
\hline Lamiaceae & 1016 & 12.83 \\
\hline Asteraceae & 886 & 11.19 \\
\hline Rosaceae & 849 & 10.72 \\
\hline Pinaceae & 569 & 7.18 \\
\hline Cistaceae & 433 & 5.47 \\
\hline Fagaceae & 427 & 5.39 \\
\hline Caryophyllaceae & 224 & 2.83 \\
\hline Berberidaceae & 218 & 2.75 \\
\hline Apiaceae & 160 & 2.02 \\
\hline Cupressaceae & 128 & 1.62 \\
\hline Thymelaeaceae & 94 & 1.19 \\
\hline Rubiaceae & 89 & 1.12 \\
\hline Brassicaceae & 87 & 1.10 \\
\hline Crassulaceae & 78 & 0.98 \\
\hline Euphorbiaceae & 65 & 0.82 \\
\hline Ranunculaceae & 64 & 0.81 \\
\hline Scrophulariaceae & 38 & 0.48 \\
\hline Rhamnaceae & 34 & 0.43 \\
\hline & &
\end{tabular}

\begin{tabular}{|c|c|c|c|}
\hline & Gnetopsida & Liliopsida & Magnoliopsid \\
\hline & 0.01 & 14.79 & 76.29 \\
\hline
\end{tabular}

Pinopsida Polypodiopsida

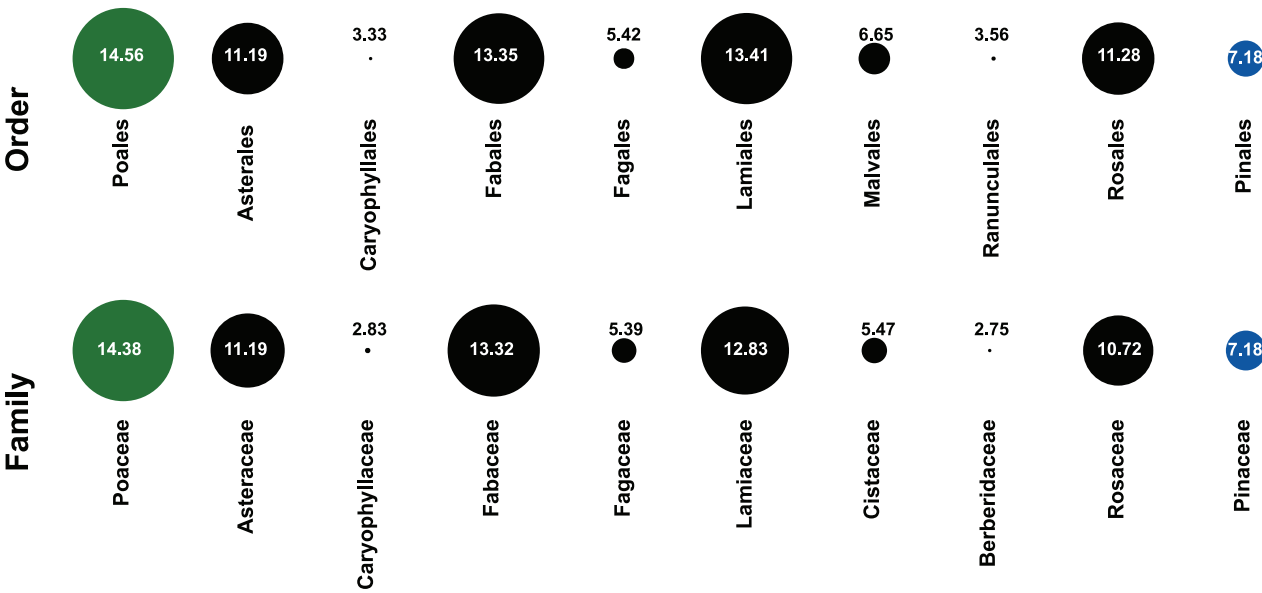

Figure 3. Taxonomic coverage. The figure shows the taxonomic coverage for class, order and family. The circles size are proportional to the number of records in the Sinfonevada database. Numbers indicates the percentage of records. All taxonomic classes included in the database are shown. For order and family rank, only the top 10 are shown. Colour indicates the taxonomic class: green (Liliopsida); black (Magnoliopsida) and blue (Pinopsida). 
Table 2. Threatened species included in SINFONEVADA dataset.

\begin{tabular}{|c|c|c|c|c|c|c|}
\hline ScientificName & Bern $^{a}$ & CITES $^{\mathbf{b}}$ & \begin{tabular}{|l|} 
Habitat \\
Directive $^{c}$ \\
\end{tabular} & \begin{tabular}{|l|} 
Spanish \\
Red List $^{\mathrm{d}}$ \\
\end{tabular} & \begin{tabular}{|l|} 
Andalusian \\
Red List $^{\mathrm{e}}$ \\
\end{tabular} & IUCN $^{f}$ \\
\hline Acer monspessulanum $\mathrm{L}$. & & & & & NT & VU \\
\hline $\begin{array}{l}\text { Acer opalus subsp. granatense (Boiss.) } \\
\text { Font Quer \& Rothm. }\end{array}$ & & & & & NT & VU \\
\hline Amelanchier ovalis Medik. & & & & & NT & LR-lc \\
\hline $\begin{array}{l}\text { Armeria filicaulis Boiss. subsp. } \\
\text { nevadensis Nieto Fel., Rosselló \& } \\
\text { Fuertes }\end{array}$ & & & & VU & VU & VU \\
\hline Celtis australis A.Rich. & & & & & NT & LR-lc \\
\hline $\begin{array}{l}\text { Centaurea bombycina Boiss. subsp. } \\
\text { bombycina }\end{array}$ & & & & VU & VU & VU \\
\hline Centaurea monticola Boiss. ex DC. & & & & VU & VU & VU \\
\hline Centaurea pulvinata (Blanca) Blanca & Appendix I & & Annex II & VU & VU & VU \\
\hline Cephalanthera longifolia (L.) Fritsch & & Annex B & & & & \\
\hline Cotoneaster granatensis Boiss. & & & & & NT & VU \\
\hline Cytisus galianoi Talavera \& P.E.Gibbs & & & & & NT & \\
\hline Erica terminalis Klotzsch & & & & & NT & VU \\
\hline Euphorbia nevadensis Boiss. \& Reut. & & & Annex IV & & NT & LR-nt \\
\hline Pinus sylvestris L. var. nevadensis Christ & & & & EN & $\mathrm{EN}$ & VU \\
\hline Potentilla reuteri Boiss. & & & & NT & NT & VU \\
\hline Prunus avium (L.) L. & & & & & & VU \\
\hline Prunus mahaleb L. & & & & & & VU \\
\hline Prunus ramburii Boiss. & & & & VU & VU & \\
\hline Quercus pyrenaica Willd. & & & & & NT & LR-cd \\
\hline Reseda complicata Bory & & & & VU & VU & \\
\hline Salix caprea L. & & & & & EN & EN \\
\hline $\begin{array}{l}\text { Salix eleagnos subsp. angustifolia } \\
\text { (Cariot) Rech.f. }\end{array}$ & & & & & & LR-cd \\
\hline Santolina elegans Boiss. ex DC. & & & Annex IV & VU & VU & VU \\
\hline Sorbus aria Wimm. ex Nyman & & & & & NT & VU \\
\hline
\end{tabular}

${ }^{a}$ Bern: Convention on the Conservation of European Wildlife and Natural Habitats (Bern Convention).

b CITES: Convention on International Trade in Endangered Species of Wild Fauna and Flora. Species included in its appendixes.

'Species included in the Habitat Directive Annex (EC 1992)

d 2010 Red List of Spanish vascular flora (Moreno 2010)

e 2005 Red List of vascular flora of Andalusia (Cabezudo et al. 2005)

${ }^{f}$ IUCN category in Sierra Nevada (IUCN 2001, Blanca et al. 1998, Blanca et al. 2001, Lorite et al. 2007)

$E N$ : Endangered; VU: Vulnerable; NT: Near threatened; LR-nt: Lower Risk-Near Threatened; LR-cd: Lower Risk-Conservation Dependent; $L R$ - $l c$ : Lower Risk-Least Concern

Family: Amaryllidaceae, Anacardiaceae, Apiaceae, Apocynaceae, Araliaceae, Asparagaceae, Asteraceae, Berberidaceae, Brassicaceae, Capparaceae, Caprifoliaceae, Caryophyllaceae, Cistaceae, Clusiaceae, Colchicaceae, Convolvulaceae, Coriariaceae, Crassulaceae, Cupressaceae, Cyperaceae, Dennstaedtiaceae, Dipsacaceae, Ephedraceae, Ericaceae, Eu- 
phorbiaceae, Fabaceae, Fagaceae, Geraniaceae, Iridaceae, Juglandaceae, Juncaceae, Lamiaceae, Leguminosae, Oleaceae, Orchidaceae, Paeoniaceae, Pinaceae, Plantaginaceae, Plumbaginaceae, Poaceae, Polygonaceae, Ranunculaceae, Resedaceae, Rhamnaceae, Rosaceae, Rubiaceae, Rutaceae, Salicaceae, Santalaceae, Sapindaceae, Scrophulariaceae, Smilacaceae, Thymelaeaceae, Ulmaceae, Umbelliferae, Urticaceae, Violaceae

\section{Spatial coverage}

General spatial coverage

The SINFONEVADA forest inventory was conducted in the main forests of Sierra Nevada mountainous region (Figure 1) (for a description of Sierra Nevada see study area of the Project section). The main forest units of Sierra Nevada (Figure 5) are pine plantations (Pinus halepensis Mill., Pinus pinaster Ait., Pinus nigra Arnold subsp. salzmannii (Dunal) Franco, and Pinus sylvestris L.), evergreen holm oak Quercus ilex subsp. ballota (Desf.) Samp forests, deciduous broadleaf forests (Quercus pyrenaica Willd, Acer opalus subsp. granatense (Boiss.) Font Quer \& Rothm., Sorbus aria (L.) Crantz), and autochthonous pine Pinus sylvestris L. var. nevadensis Christ forests.

\section{Coordinates}

$36^{\circ} 52^{\prime} 12^{\prime \prime} \mathrm{N}$ and $37^{\circ} 15^{\prime} 36^{\prime \prime} \mathrm{N}$ Latitude; $3^{\circ} 41^{\prime} 24^{\prime \prime} \mathrm{W}$ and $2^{\circ} 33^{\prime} 36^{\prime \prime W}$ Longitude

\section{Temporal coverage}

2004-2005

\section{Natural collections description}

Parent collection identifier: NA

Collection name: Sinfonevada: Dataset of floristic diversity in Sierra Nevada forest (SE Spain)

\section{Collection identifier}

http://www.gbif.es:8080/ipt/manage/metadata-collections.do?r=sinfonevada 


\section{Methods}

\section{Method step description}

This inventory was undertaken in 2004 and the database generated contains information relative to forest attributes and occurrence data (see below). This information, originally stored in a Microsoft Access database, has been integrated into the project's information system.

Study extent description: The floristic inventories were conducted at the main forest units of the Sierra Nevada (Andalusia, SE Spain). Forest cover in Sierra Nevada is dominated by pine plantations (Pinus halepensis Mill., Pinus pinaster Ait., Pinus nigra Arnold subsp. salzmannii (Dunal) Franco, and Pinus sylvestris L.) covering approximately 40,000 ha. Most of them were planted in the period 1960-1980. The main native forests of Sierra Nevada are dominated by the evergreen holm oak Quercus ilex subsp. ballota (Desf.) Samp. occupying low and medium mountain areas $(8,800$ ha.) and Pyrenean oak Quercus pyrenaica Willd ranging from 1,100 to 2,000 m a.s.l., covering about 2,000 ha. Autochthonous pine P. sylvestris var. nevadensis forests can also be found in small patches at high altitudes with a characteristically low tree cover.

Sampling description: SINFONEVADA Forest Inventory was established over an extensive network of 600 long-term permanent plots distributed within the main forest units of the Sierra Nevada: pine plantations, evergreen Q. ilex forests, and deciduous broadleaf forests. The network of plots is a random sample stratified by land cover and altitude, covering a gradient of 974-2439 m a.s.l. (Figure 5).

Each inventory plot has three sampling units: i) a forest inventory plot $(20 \times 20 \mathrm{~m})$; ii) a 5-m radius subplot for the estimation of the regeneration; iii) and a 10-m radius subplot for species composition and abundance.

Each live tree with a diameter at breast height $(\mathrm{dbh})>7.5 \mathrm{~cm}$ was tallied by species and dbh in the forest inventory plot. This information was used to calculate forest attributes (tree basal area, tree volume, canopy cover). The regeneration was measured in the 5 - $\mathrm{m}$ radius subplot $\left(78.5 \mathrm{~m}^{2}\right.$ in area) as seedling abundance of the main tree species.

The species composition and diversity was recorded within a $10-\mathrm{m}$ radius subplot $\left(314 \mathrm{~m}^{2}\right.$ in area) using the Braun-Blanquet cover-abundance scale (Braun-Blanquet 1964).

\section{Quality control description}

Prior to the storing of this information in the database, all the data were assessed by a quality-control process. Each sampling plot was checked to ensure that the geographical coordinates were correct. We used the databases of International Plant Names Index (IPNI 2013) and Catalogue of Life/Species 2000 (Roskov et al. 2013) to verify the taxonomical classification. The specimens were taxonomically identified using Flora Iberica (Castroviejo et al. 1986-2005) for the published families while the rest of taxa were identified according to Valdés et al. (1987) and Tutin et al. (1964-1980). 


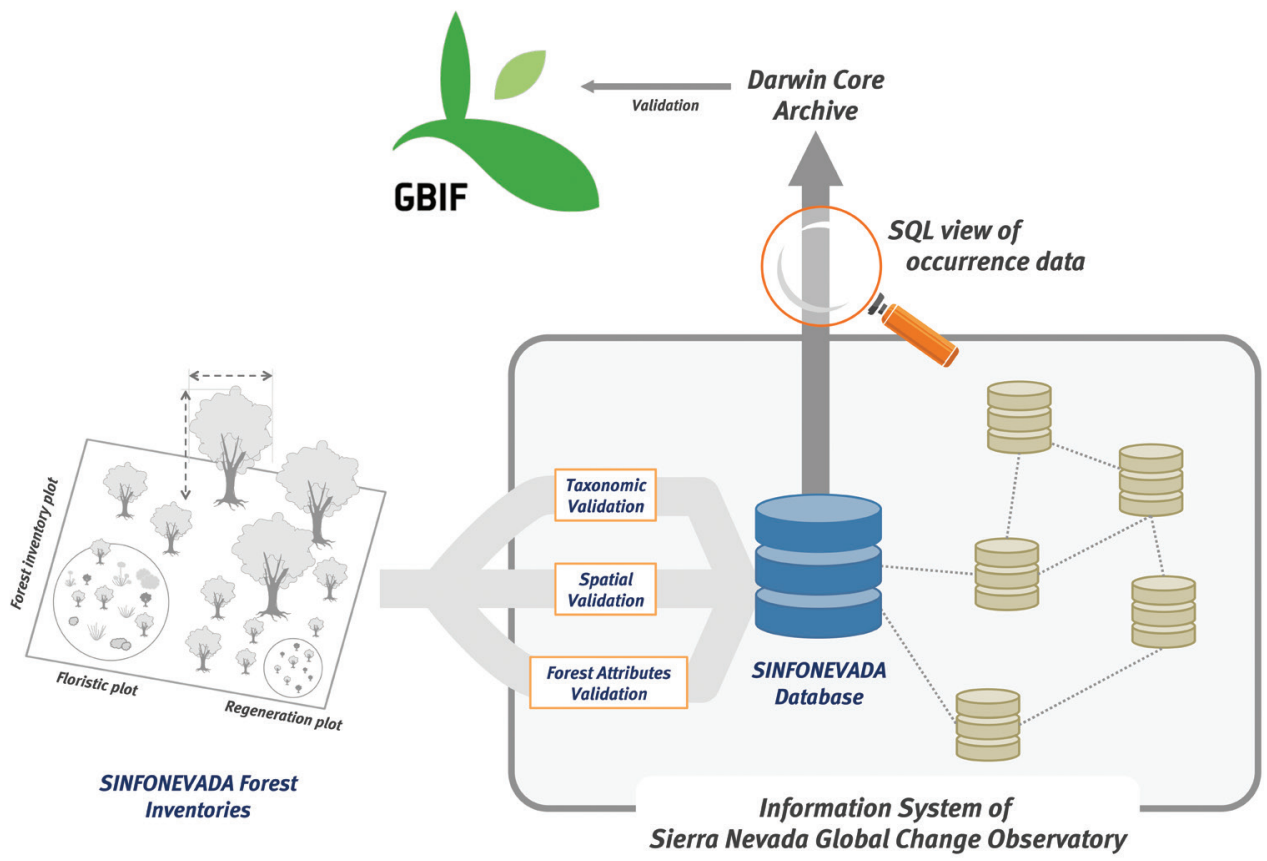

Figure 4. Diagram of integration of SINFONEVADA within Information System of Sierra Nevada Global Change Observatory. The original database of SINFONEVADA contains two types of information: forest attributes and related information and occurrence data. This information was integrated into the Information System of Sierra Nevada Global Change Observatory. After a validation process (see Quality Control section) the occurrence data were accommodated to Darwin Core Archive to integrate in GBIF.

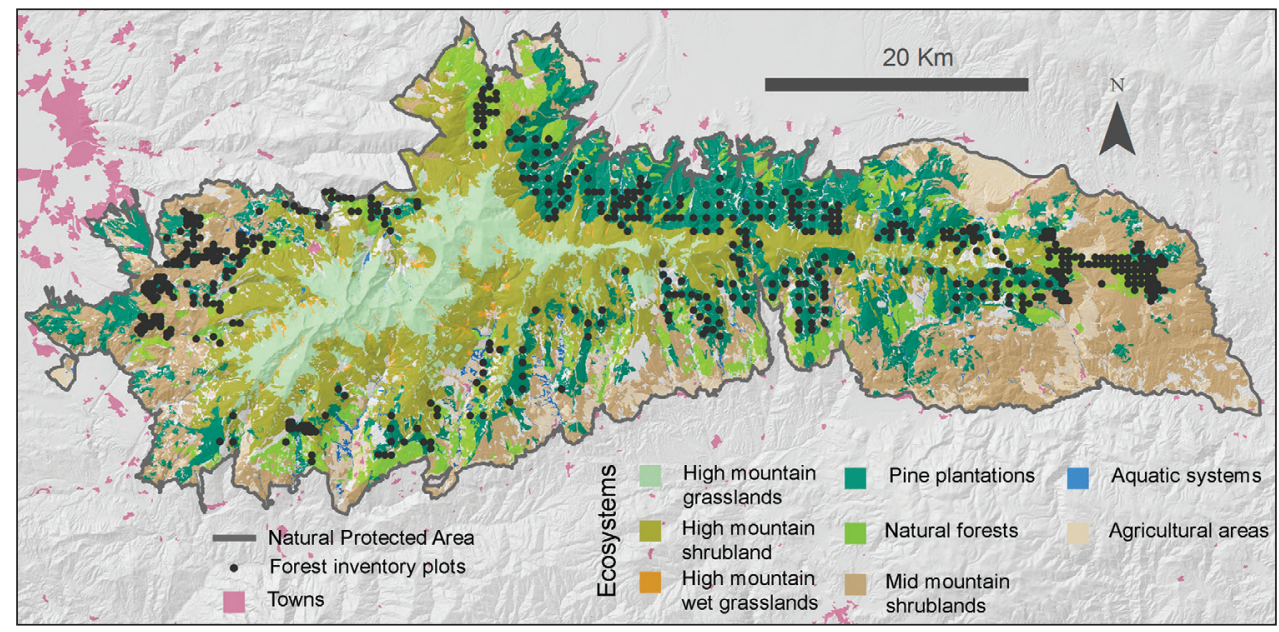

Figure 5. Location of the forest-inventory plots. This map shows the location of the forest-inventory plots and the distribution of the ecosystem types present in Sierra Nevada. The vegetation is predominantly high-mountain shrublands and pine plantations, with some natural forests (oaks, Pyrenean oaks, maples, etc.). 


\section{Datasets}

The original database of SINFONEVADA contains two types of information: forest attributes (and related information), and occurrence data. There are several national forest inventories (Spanish National Forest Inventory, Alberdi et al. 2010) that have partially monitored some forests of Sierra Nevada. However, due to grain size, none have been as exhaustive as the SINFONEVADA inventory.

The original SINFONEVADA database was incorporated into the Information System of Sierra Nevada Global Change Observatory (Figure 4). Taxonomic and spatial validations were made on this database. Also, we carried out quality control procedures for forest attributes (detection of atypical values). A custom-made SQL view of the original SINFONEVADA was performed to gather occurrence data. The view shows occurrence data collected in the floristic inventories associated with the forest inventory. We included only records that had been accepted for publication. The occurrence data were accommodated to the Darwin Core Archive to integrate in GBIF. We used Darwin Core Archive Validator tool (http://tools.gbif.org/dwca-validator/) to check whether the dataset meets Darwin Core specifications. The Integrated Publishing Toolkit (IPT v2.0.5) of the Spanish node of the Global Biodiversity Information Facility (GBIF) (http://www.gbif.es:8080/ipt) was used both to upload the Darwin Core Archive and to fill out the metadata. Information about forest attributes included in the original SINFONEVADA database is available upon request.

The fields provided by the SINFONEVADA dataset are:

occurrenceld, modified, basisOfRecord, institutionCode, collectionCode, catalogNumber, occurrenceRemarks, scientificName, kingdom, phylum, class, order, family, genus, specificEpithet, infraspecificEpithet, scientificNameAuthorship, continent, country, stateProvince, county, locality, minimumElevationInMeters, maximumElevationInMeters, recordedBy, identifiedBy, dateIdentified, decimalLongitude, decimalLatitude, coordinateUncertaintyinMeters.

The SINFONEVADA dataset represents an exhaustive floristic inventory of diversity of Sierra Nevada forest. It includes occurrences of 270 taxa, of which 24 are considered threatened and 9 endemic (Table 2). Information of SINFONEVADA has been used for the Natural Resources Ordinance Plan of the Sierra Nevada Natural Area (CMA 2011). Also its information provides valuable support to natural-resource managers in their decision making. It is being considered for management actions within strategies of diversification and naturalization of forests in the Sierra Nevada natural area.

\section{Dataset description}

Object name: Darwin Core Archive Sinfonevada: Dataset of floristic diversity in Sierra Nevada forest (SE Spain)

Character encoding: UTF-8.

Format name: Darwin Core Archive format. 
Format version: 1.0

Distribution: http://www.gbif.es:8080/ipt/archive.do? $r=s i n f o n e v a d a$

Publication date of data: 2013-09-24

Language: English.

Licenses of use: The "Sinfonevada: Dataset of floristic diversity in Sierra Nevada forest (SE Spain)" dataset is made available under the Open Data Commons Attribution License: http://www.opendatacommons.org/licenses/by/1.0/.

Metadata language: English.

Date of metadata creation: 2013-06-18

Hierarchy level: Dataset.

\section{Acknowledgements}

We thank to Katia Cezón, Cristina Valverde and Franciso Pando (Spanish GBIF nodeCSIC) for technical support. We thank David Nesbitt for linguistic advice.

This research work was conducted in the collaborative framework of the "Sierra Nevada Global Change Observatory" Project from the Environment Department of Andalusian Regional Government and the Sierra Nevada National Park. MIGRAME project (RNM 6734) from the Excellence Research Group Programme of the Andalusian Government also provided funding. We would like to thank Empresa de Transformación Agraria S.A. (TRAGSA) for conducting the forest inventory. A. J. Pérez-Luque would like to thank the MICINN of the Government of Spain for the financial support (PTA 2011-6322-I)

\section{References}

\section{1) References cited within metadata}

Alberdi I, Condés S, Martínez-Millán J, Saura S, Sánchez G, Pérez-Martín F, Villanueva JA, Vallejo, R (2010) National Forest Inventory Report: Spain. In: Tomppo E, Gschwantner T, Lawrence M, McRoberts RE (Eds) National Forest Inventories. Pathways for Common Reporting. Springer, 527-540.

Aspizua-Cantón R, Barea-Azcón JM, Bonet FJ, Pérez-Luque AJ, Zamora R (Eds) (2012) Observatorio de Cambio Global Sierra Nevada: metodologías de seguimiento. Consejería de Medio Ambiente, Junta de Andalucía, 1-112.

Aspizua-Cantón R, Bonet FJ, Zamora R, Sánchez FJ, Cano-Manuel FJ, Henares I (2010) El observatorio de cambio global de Sierra Nevada: hacia la gestión adaptativa de los espacios naturales. Ecosistemas 19 (2): 56-68. http://www.revistaecosistemas.net/index.php/ecosistemas/article/view/46

Blanca G, Cueto M, Martínez-Lirola MJ, Molero-Mesa J (1998) Threatened vascular flora of Sierra Nevada (Southern Spain). Biological Conservation 85 (3): 269-285. doi: 10.1016/ S0006-3207(97)00169-9 
Björnsen A (Ed) (2005) The GLOCHAMORE (Global Change and Mountain Regions) Research Strategy. Berne (Switzerland) and Vienna (Austria). Mountain Research Initiative Office and University of Vienna, 1- 48. http://unesdoc.unesco.org/ images/0014/001471/147170E.pdf

Bonet FJ, Pérez-Luque AJ, Moreno R, Zamora R (2010) Sierra Nevada Global Change Observatory. Structure and Basic Data. Environment Department (Andalusian Regional Government)-University of Granada, 1-48.

Bonet FJ, Aspizua-Cantón R, Zamora R, Sánchez FJ, Cano-Manuel FJ, Henares I (2011) Sierra Nevada Observatory for monitoring global change: Towards the adaptive management of natural resources. In: Austrian MaB Comitee (Ed) Biosphere Reserves in the mountains of the world. Excellence in the clouds?. Austrian Academy of Sciences Press, Vienna, 48-52.

Cabezudo B, Talavera S, Blanca G, Salazar C, Cueto M, Valdés B, Hernández Bermejo JE, Herrera CM, Rodríguez-Hiraldo C, Navas D (2005) Lista roja de la flora vascular de Andalucía, Consejería de Medio Ambiente, Junta de Andalucía. Sevilla.

CMA (2011) Decreto 238/2011, de 12 de Julio, por el que se establece la ordenación y gestión de Sierra Nevada. BOJA 155 (9 de Agosto de 2011): 114-314. Consejería de Medio Ambiente, Junta de Andalucía. http://www.juntadeandalucia.es/boja/2011/155/d3.pdf

IPNI (2013) The International Plant Names Index. http://www.ipni.org [accessed 05. 05.2013]

Lorite J, Navarro FB, Valle F (2007) Estimation of threatened orophytic flora and priority of its conservation in the Baetic range (S. Spain). Plant Biosystems 141(1): 1-14. doi: $10.1080 / 11263500601153560$

Moreno JC (Coord.) (2008) Lista Roja de la Flora Vascular Española. Actualización con los datos de la Adenda 2010 al Atlas y Libro Rojo de la Flora Vascular Amenazada. Dirección General de Medio Natural y Politica Forestal (Ministerio de Medio Ambiente y Medio Rural y Marino), y Sociedad Española de Biologia de la Conservacion de Plantas), Madrid, 86 pp.

Pérez-Pérez R, Bonet FJ, Pérez-Luque AJ, Zamora R (2012) Linaria: a set of information management tools to aid environmental decision making in Sierra Nevada (Spain) LTER site. In: Long Term Ecological Research (LTER) (Ed) Proceedings of the 2013 LTER All Scientist Meeting: The Unique Role of the LTER Network in the Antropocene: Collaborative Science Across Scales. LTER, Estes Park - Colorado (EE.UU).

Roskov Y, Kunze T, Paglinawan L, Abucay L, Orrell T, Nicolson D, Culham A, Bailly N, Kirk P, Bourgoin T, Baillargeon G, Hernandez F, De Wever A, Didžiulis V (Eds) (2013) Species 2000 \& ITIS Catalogue of Life. Species 2000: Reading, UK. http://www.catalogueoflife.org/col [accessed 05.05.2013]

Schaaf T (2009) Mountain Biosphere Reserves-A People Centred Approach that also Links Global Knowledge. Sustainable Mountain Development 55: 13-15. http://lib.icimod.org/ record/26505/files/c_attachment_601_5624.pdf

Zamora R, Bonet FJ (2011) Programa de Seguimiento del Cambio Global en Sierra Nevada: ciencia y tecnología para la gestión adaptativa. Boletín de la RED de seguimiento del cambio global en Parques Nacionales 1: 18-24. http://reddeparquesnacionales.mma.es/ parques/rcg/html/rcg_boletin_01.htm 


\section{2) References used to build the dataset}

Blanca G, López Onieva MR, Lorite J, Martínez Lirola MJ, Molero Mesa J, Quintas S, Ruíz Girela M, Varo MA, Vidal S (2001) Flora amenazada y endémica de Sierra Nevada. Consejería de Medio Ambiente. Junta de Andalucía.

CMA (1995) Plan de Ordenación de los Recursos Naturales y Plan Rector de Uso y Gestión del Parque Natural de Sierra Nevada. Junta de Andalucía, Consejería de Medio Ambiente. Sevilla. Braun-Blanquet J (1964) Pflanzensoziologie. Springer Verlag, Wien, New York, 1-865.

Castroviejo S (Ed) (1986-2005) Flora Iberica. Real Jardín Botánico CSIC, Madrid.

Castroviejo S (Ed) (2001) Claves de Flora Ibérica. Plantas Vasculares de la Península Ibérica e Islas Baleares. Volumen 1. Consejo Superior de Investigaciones Científicas. Real Jardín Botánico, Madrid.

Philip MS (1994) Measuring Trees and Forests. UK, CAB International. Tutin TG et al. (Eds) (1964-1980) Flora Europaea, Cambridge University Presss, Cambridge, 1-5.

Ministerio de Medio Ambiente (1998) Segundo inventario forestal nacional 1986-1995. Dirección General Conservación de la Naturaleza, Madrid.

Molero Mesa J, Pérez-Raya F (1987) La flora de Sierra Nevada. Avance sobre el catálogo florístico nevadense. Universidad de Granada. Granada.

Molero Mesa J, Pérez Raya F, López Nieto JM, El Aallali A, Hita Fernández JA (2001) Cartografía y evaluación de la vegetación del Parque Natural de Sierra Nevada. Consejería de Medio Ambiente. Junta de Andalucía. Sevilla.

Valdés B, Talavera S, Fernández-Galiano E (Eds) (1987) Flora vascular de Andalucía Occidental, 1-3. Ketres, Barcelona.

\section{3) Publication using data of this dataset}

Gómez-Aparicio L, Zavala MA, Bonet-García FJ, Zamora R (2009) Regeneración y diversidad en pinares de repoblación: un análisis a través de gradientes ambientales. In: Sociedad Española de Ciencias Forestales (Ed) $5^{\circ}$ Congreso Forestal Español. Montes y Sociedad: Saber qué hacer, Ávila. http://www.secforestales.org/buscador/pdf/5CFE01-027.pdf

Gómez-Aparicio L, Zavala MA, Bonet-García FJ, Zamora R (2009) Are pine plantations valid tools for restoring Mediterranean forests? An assessment along abiotic and biotic gradients. Ecological Applications 19 (8): 2124-2141. doi: 0.1890/08-1656.1

González-Moreno P (2009) Natural regeneration and biodiversity in pine plantations of Southern Spain: a landscape approach, Master's Thesis, Wageningen University, Netherlands.

González-Moreno P, Quero JL, Bonet FJ, Poorter L, Zamora R (2009) El papel de la estructura espacial de la vegetación en la naturalización de pinares de repoblación en Sierra Nevada (Granada-Almería). In: Sociedad Española de Ciencias Forestales (Ed) $5^{\circ}$ Congreso Forestal Español. Montes y Sociedad: Saber qué hacer, Ávila. http://www.secforestales.org/ buscador/pdf/5CFE01-065.pdf

González-Moreno P, Quero JL, Bonet FJ, Poorter L, Zamora R (2010) The influence of spatial structure on natural regeneration and biodiversity in Mediterranean pine plantations: a nested landscape approach. In: Azevedo J, Feliciano M, Castro J, Pinto MA (Eds) Proceedings of the IUFRO Landscape Ecology Working Group International Conference: Forest 
landscapes and global change new frontiers in management, conservation and restoration. Instituto Politécnico de Bragança, Portugal, 52-57.

González-Moreno P, Quero JL, Bonet FJ, Poorter L, Zamora R (2011) Is spatial structure the key to promote plant diversity in Mediterranean forest plantations?. Basic and Applied Ecology 12 (3): 251-259. doi: 10.1016/j.baae.2011.02.012

Navarro-González I (2009) Efectos del uso pasado del suelo en la regeneración actual de la vegetación natural bajo las plantaciones de pinares de Sierra Nevada. Implicaciones en la gestión forestal. Master's Thesis, Universidad Autónoma de Madrid - Universidad Complutense de Madrid - Universidad de Alcalá, Spain.

Navarro-González I, Bonet-García FJ, Zamora R (2011) Current Mediterranean forest regeneration depends on land use in the recent past. In: European Ecological Federation (Ed) Proceedings of the12th European Ecological Federation Congress: Responding to Rapid Environmental Change, Asociación Española de Ecología Terrestre, Ávila, Spain, 420.

Navarro-González I, Pérez-Luque AJ, Bonet FJ, Zamora R (2013) The weight of the past: Land-use legacies and recolonization of pine plantations by oak trees. Ecological Applications 23:1267-1276. doi: 10.1890/12-0459.1

Pérez-Luque AJ (2011) Análisis multivariante ambiental de los melojares de Quercus pyrenaica Willd. de Sierra Nevada. Master's thesis, Universidad de Granada, Spain. http://refbase. iecolab.es/files/perez-luque/2011/1661_Perez-Luque2011.pdf

Pérez-Luque AJ, Bonet FJ, Benito BM, Zamora R (2013). Caracterización ambiental de los robledales de Quercus pyrenaica Willd. de Sierra Nevada. In: Asociación Espańola de Ecología Terrestre (Ed) Proceedings of the XI Congreso Nacional de la Asociación Española de Ecología Terrestre, Invitación a la Ecología. Asociación Española de Ecología Terrestre, Pamplona, 92. doi: 10.7818/AEET.XICongress.2013 
